\title{
Protein Aggregation, Radical Scavenging Capacity, and Stability of Hydrogen Peroxide Defense Systems in Heat-stressed Vinca and Sweet Pea Leaves
}

\author{
Jeffrey A. Anderson ${ }^{1}$ and Sonali R. Padhye \\ Department of Horticulture and Landscape Architecture, 360 Agriculture Hall, Oklahoma State \\ University, Stillwater, OK 74078-6027
}

\begin{abstract}
ADDITIONAL INDEX wORDS. activated oxygen species, ascorbate peroxidase, catalase, Catharanthus roseus, electrolyte leakage, Lathyrus odoratus, thermotolerance, turbidity

Abstract. Although heat stress injury is known to be associated with membrane dysfunctions, protein structural changes, and reactions of activated forms of oxygen, the underlying mechanisms involved are poorly understood. In this study, the relationships between thermotolerance and hydrogen peroxide $\left(\mathrm{H}_{2} \mathrm{O}_{2}\right)$ defense systems, radical scavenging capacity [based on 1,1-diphenyl-2-picrylhydrazyl (DPPH) reduction], and protein aggregation were examined in vinca [Catharanthus roseus (L.) G. Don 'Little Bright Eye'], a heat tolerant plant, and sweet pea (Lathyrus odoratus L. 'Explorer Mix'), a heat susceptible plant. Vinca leaves were $5.5^{\circ} \mathrm{C}$ more thermotolerant than sweet pea leaves based on electrolyte leakage analysis. Vinca leaf extracts were more resistant to protein aggregation at high temperatures than sweet pea leaf extracts, with precipitates forming at $\geq 40{ }^{\circ} \mathrm{C}$ in sweet pea and at $\geq 46^{\circ} \mathrm{C}$ in vinca. Vinca leaves also had nearly three times greater DPPH radical scavenging capacity than sweet pea leaf extracts. Two enzymatic detoxifiers of $\mathrm{H}_{2} \mathrm{O}_{2}$, catalase (CAT) and ascorbate peroxidase (APOX), demonstrated greater activities in vinca leaves than in sweet pea leaves. In addition, CAT and APOX were more thermostable in vinca, compared with sweet pea leaves. However, tissue $\mathrm{H}_{2} \mathrm{O}_{2}$ levels did not differ between controls and tissues injured or killed by heat stress in either species, suggesting that $\mathrm{H}_{2} \mathrm{O}_{2}$ did not play a direct role in acute heat stress injury in vinca or sweet pea leaves. Greater thermotolerance in vinca, compared with sweet pea, was associated with greater DPPH radical scavenging capacity, indicating that AOS other than $\mathrm{H}_{2} \mathrm{O}_{2}$ may be involved in acute heat stress injury.
\end{abstract}

\begin{abstract}
Abiotic stresses, including temperature extremes, are among the primary causes of diminished plant quality, reduced cropyields, and loss of viability. Heat stress damages cellular structure and metabolic pathways, and contributes to secondary water stress (Levitt, 1980). Injury is evidenced by decreased leaf chlorophyll content (Liu and Huang, 2000), peroxidation of membrane lipids (Nanaiah and Anderson, 1992), and protein denaturation and aggregation (Salvucci et al., 2001). Acute heat stress injury probably involves changes in structure and function of membranes and proteins.

Temperature extremes can reduce enzymatic function and protein solubility through changes in intra- and intermolecular bonds of proteins. These noncovalent bonds can be broken at elevated temperatures, leading to denaturation, a complex process involving intermediate folding stages (Buchner et al., 1998). Heat shock proteins influence heat tolerance of plants by stabilizing folding intermediates (Jakob et al., 1995). If not protected, denatured proteins can aggregate irreversibly and form hydrophobic or electrostatic interactions with other unfolded proteins. Although scientists have recognized the differences between subtle conformational changes that may affect enzymatic activity and gross changes in solubility, it has been known for many decades that plant protoplasts coagulate at elevated temperatures (Levitt, 1980). Levitt (1980) cited reports from several researchers indicating that protein denaturation, cellular coagulation, and loss of viability were integrally related. Treatments that altered protein

Received for publication 28 Feb. 2003. Approved for publication 22 Sept. 2003. Approved for publication by the director of the Oklahoma Agricultural Experiment Station. Research supported by the Oklahoma Agricultural Experiment Station. Mention of a trademark, proprietary product, or vendor does not constitute a guarantee or warranty of the product and does not imply its approval to the exclusion of other products or vendors that also may be suitable.

${ }^{1}$ Corresponding author; e-mail jander@okstate.edu.
\end{abstract}

stability had a corresponding effect on heat tolerance of bacteria and algae (Levitt, 1980).

In addition to protein stability, generation and reactions of activated oxygen species (AOS) are involved in plant responses to temperature stress. Activated oxygen species, including singlet oxygen, superoxide, hydrogen peroxide $\left(\mathrm{H}_{2} \mathrm{O}_{2}\right)$, and the hydroxyl radical, can react with pigments, membranes, enzymes, and nucleic acids, thereby modifying their functions (Elstner, 1982). Autocatalytic peroxidation of membrane lipids triggered by AOS results in loss of membrane semipermeability (Basaga, 1989), one of the primary symptoms of stress injury (Foyer et al., 1997).

However, production of AOS in plants is not restricted to stressful conditions because formation occurs during fatty acid $\beta$-oxidation (del Rio et al., 1998) and photorespiration (VeljovicJovanovic, 1998). Activated oxygen species are also produced under normal conditions by membrane-associated oxidases (Desikan et al., 1996), and as byproducts from electron transport chains (Shewfelt and Purvis, 1995). Activated oxygen species can perform beneficial or deleterious functions in cells. For example, $\mathrm{H}_{2} \mathrm{O}_{2}$ benefits plants by polymerizing a lignin precursor during cell wall lignification (Gross, 1980), and can serve as a second messenger in signal transduction pathways leading to temperature stress acclimation (Foyer et al., 1997). Activated oxygen species can also contribute to senescence during normal developmental processes (Dhindsa et al., 1981). The type and concentration of AOS are key factors determining the beneficial or harmful functions of AOS. Hydroxyl radicals are so reactive that they normally cause random destruction at the point of formation. Less reactive molecules, such as $\mathrm{H}_{2} \mathrm{O}_{2}$, can injure cells at high concentrations, or lead to acclimation at moderate levels (Foyer et al., 1994; Prasad et al., 1994). 
Several enzymatic and nonenzymatic antioxidant defense systems tightly control AOS concentrations to protect cells from damage (Noctor and Foyer, 1998). The primary enzymatic defenses include superoxide dismutase (SOD; EC = 1.15.1.1), catalase (CAT; $\mathrm{EC}=1.11 .1 .6)$, peroxidase (POX; EC:1.11.1.7), ascorbate peroxidase (APOX; $\mathrm{EC}=1.11 .1 .11)$, and glutathione reductase $(\mathrm{GR} ; \mathrm{EC}=1.8 \cdot 1.7)$. Nonenzymatic defenses include glutathione, $\alpha$-tocopherol, ascorbate, $\beta$-carotene, hydroquinones, flavonoids, phenols, and phenolic acids (Elstner, 1982; Larson, 1988). Typically, antioxidants provide adequate protection against the deleterious effects of AOS (Alscher et al., 1997). However, increased AOS were observed in plants exposed to chilling (Wise and Naylor, 1987) and heat stress (Dat et al., 1998). Acclimation treatments can increase antioxidant activity, detoxifying heavy loads of AOS and providing protection against chilling injury (Prasad et al., 1999; Sala and Lafuente, 1999). Acclimated maize (Zea mays L.) seedlings had increased CAT activity and modestly increased $\mathrm{H}_{2} \mathrm{O}_{2}$ levels after chilling, but nonacclimated seedlings had large increases in $\mathrm{H}_{2} \mathrm{O}_{2}$ (Prasad et al., 1994). However, $\mathrm{H}_{2} \mathrm{O}_{2}$ content and activities of APOX and CAT were poorly correlated when comparing heat tolerant and susceptible wheat genotypes at different planting dates and stages of development (Sairam et al., 2000). Hydrogen peroxide levels were unchanged in heatstressed pepper leaves (Anderson, 2002) and reduced in several plant species exposed to chilling temperatures (MacRae and Ferguson, 1985) despite reduced enzymatic defenses. The role of $\mathrm{H}_{2} \mathrm{O}_{2}$ in chilling injury appears to depend on plant species and environmental conditions before and during exposure. Hydrogen peroxide involvement in heat stress injury is not clear.

In addition to studies focusing on activities of enzymes involved in AOS detoxification, scavenging activity has been monitored using relatively stable free radicals. Kang and Saltveit (2002) reported increased 1,1-diphenyl-2-picrylhydrazyl (DPPH) radical scavenging activity being associated with heat shock-induced chilling resistance in rice (Oryza sativa L.) seedlings. Antioxidant activity has also been determined in microorganisms (Abe et al., 1998) and plant leaf extracts (Masuda et al., 1999) using the DPPH radical.

Determining relationships between thermotolerance and AOS defenses, membrane integrity, and protein stability are essential in understanding the underlying basis for heat tolerance in plants. Therefore, the objectives of this study were to use a heat-tolerant bedding plant, vinca (Catharanthus roseus L.), and heat-susceptible sweet pea (Lathyrus odoratus L.) to 1) determine the relationship between leaf thermotolerance and the stability of CAT and APOX; 2) assess the effect of heat stress on endogenous $\mathrm{H}_{2} \mathrm{O}_{2} ; 3$ ) evaluate if vinca and sweet pea leaves differed in DPPH radical scavenging capacity; and 4) test whether plant extracts differed in resistance to heat-induced aggregation and precipitate formation.

\section{Materials and Methods}

Plant culture. Vinca and sweet pea seeds were sown in 15-cm-diameter pots in a commercial potting mix (Universal mix, Strong-lite, Pine Bluff, Ark.) enriched with micronutrients. Amendments included dolomite $\left(3.6 \mathrm{~g} \cdot \mathrm{L}^{-1}\right)$, superphosphate $(0.7$ $\left.\mathrm{g} \cdot \mathrm{L}^{-1}\right)$, Micromax (The Scotts Co., Marysville, Ohio) $\left(0.6 \mathrm{~g} \cdot \mathrm{L}^{-1}\right)$, and $\mathrm{KNO}_{3}\left(0.6 \mathrm{~g} \cdot \mathrm{L}^{-1}\right)$. Plants were grown in controlled environment chambers (model PGW36; Conviron, Winnipeg, Man., Canada) at $24 / 20{ }^{\circ} \mathrm{C}$ (day/night) cycles, with $45 \%$ to $65 \%$ relative humidity. The chamber was programmed for $14-\mathrm{h}$ photoperiods with a photosynthetic photon flux density at canopy height of about $400 \mu \mathrm{mol} \cdot \mathrm{m}^{-2} \cdot \mathrm{s}^{-1}$. Plants were fertigated with $20 \mathrm{~N}-8.6 \mathrm{P}-16.6 \mathrm{~K}$ soluble fertilizer (J.R. Peters, Allentown, Pa.) at $0.7 \mathrm{~g} \cdot \mathrm{L}^{-1}$ as needed, based on soil color and pot weight.

Electrolyte leakage. Leaf thermotolerance was assessed by electrolyte leakage. Leaf disks ( $7 \mathrm{~mm}$ diam) from 8 -week-old plants were prepared with a cork borer and placed in $25 \times 150$ $\mathrm{mm}$ test tubes with $2 \mathrm{~mL}$ distilled water. Only fully expanded, nonsenescent leaves were used. High temperature treatments were administered for $15 \mathrm{~min}$ by placing the test tubes into a circulating water bath at the desired temperature. Temperatures tested were $24{ }^{\circ} \mathrm{C}$ for the controls, 50 to $58^{\circ} \mathrm{C}$ for vinca, and 44 to $52{ }^{\circ} \mathrm{C}$ for sweet pea, at $1^{\circ} \mathrm{C}$ intervals. Three subsamples were assayed for each temperature exposure. After temperature treatments, $20 \mathrm{~mL}$ distilled water was added to the test tubes and samples were incubated on an orbital shaker for $22 \mathrm{~h}$ at $24{ }^{\circ} \mathrm{C}$. Initial conductivity was measured using a conductivity meter (model 35; Yellow Springs Instrument Company, Yellow Springs, Ohio). Samples were then autoclaved for $20 \mathrm{~min}$, followed by another 22 $\mathrm{h}$ incubation before final conductivity measurements were taken. Electrolyte leakage (EL) was computed as the ratio of initial to final conductivity $\times 100$. The midpoint of the EL-temperature response curve $\left(\mathrm{T}_{\text {mid }}\right)$ was determined as described by Ingram (1985) using PROC NLIN (SAS Institute, Cary, N.C.).

Thermostability of CAT AND APOX. Leaf tissue $(1 \mathrm{~g})$, excluding the midrib, was cut into approximately $1-\mathrm{cm}^{2}$ pieces and placed in a $25 \times 150 \mathrm{~mm}$ test tube with $2 \mathrm{~mL}$ distilled water for high temperature treatments. The test tubes were placed into a circulating water bath for $15 \mathrm{~min}$ for each high temperature exposure. Temperatures tested were $24{ }^{\circ} \mathrm{C}$ for the controls, 48 to $64{ }^{\circ} \mathrm{C}$ for vinca, and 42 to $58^{\circ} \mathrm{C}$ for sweet pea, at $2{ }^{\circ} \mathrm{C}$ intervals. Heat-treated tissue was homogenized in a blender (Waring Products Div., Dynamics Corp., New Hartford, Conn.) along with $0.08 \mathrm{~g}$ polyvinylpolypyrrolidone (PVPP) and $25 \mathrm{~mL}$ potassium phosphate buffer (50 mM, pH 7.0), then filtered through Miracloth (Calbiochem-Novabiochem Corp., San Diego) premoistened with buffer. Filtrate was centrifuged at $16,000 g_{n}$ for $15 \mathrm{~min}$ and the supernatant was used as crude extract.

Catalase activity in the crude extract was determined spectrophotometrically by recording the decrease in absorbance at $240 \mathrm{~nm}$ for $10 \mathrm{~s}$ after a 10-s lag (Aebi, 1983). The $3 \mathrm{~mL}$ reaction mixture contained $1.5 \mathrm{~mL}$ of a 1:20 dilution of crude plant extract and 1.5 $\mathrm{mL} 30 \mathrm{mM} \mathrm{H}_{2} \mathrm{O}_{2}$ prepared in buffer, which initiated the reaction. Ascorbate peroxidase activity was determined spectrophotometrically by recording the decrease in absorbance at $290 \mathrm{~nm}$ for $50 \mathrm{~s}$ after a $10 \mathrm{~s}$ lag (Miyake et al., 1991). The $3 \mathrm{~mL}$ reaction mixture contained $1 \mathrm{~mL}$ of a 1:10 dilution of crude plant extract, $0.8 \mathrm{~mL}$ $50 \mathrm{~mm}$ phosphate buffer $(\mathrm{pH} 7.0)$ and $0.6 \mathrm{~mL} 1.0 \mathrm{~mm}$ ascorbate. The reaction was initiated by addition of $0.6 \mathrm{~mL} 0.5 \mathrm{~mm} \mathrm{H}_{2} \mathrm{O}_{2}$. All reagents were prepared in buffer. In both enzyme assays, crude plant extracts were analyzed in three subsamples.

Activity midpoint temperatures $\left(\mathrm{T}_{\text {mid }}\right)$ were calculated for APOX and CAT activity using PROC NLIN. The experiment was a split-plot arrangement in a randomized complete block design with five experimental dates (replications) constituting the blocks. Plant species were levels of the main unit factor, and EL, APOX, and CAT were levels of the split unit factor. Analysis of variance was performed using PROC MIXED (SAS Institute).

HYDROGEN PEROXIDE LEVELS IN CONTROL, INJURED, AND KILLED TISSUES. Leaf disks ( $7 \mathrm{~mm}$ diam) were prepared for measurement of EL and $0.5 \mathrm{~g}$ leaf tissue was cut into 1-cm strips for measurement of $\mathrm{H}_{2} \mathrm{O}_{2}$. The leaf disks or strips were placed in $25 \times 150 \mathrm{~mm}$ 
test tubes with $2 \mathrm{~mL}$ distilled water and exposed to 24,54 , or 60 ${ }^{\circ} \mathrm{C}$ for vinca, and 24,48 , or $54{ }^{\circ} \mathrm{C}$ for sweet pea in a circulating water bath for $15 \mathrm{~min}$.

Hydrogen peroxide content of the tissue was determined spectrophotometrically using a modification of the procedure described by Ngo and Lenhoff (1980). After the temperature treatment, $0.5 \mathrm{~g}$ leaf tissue was frozen in liquid nitrogen. Five milliliters chilled 5\% trichloroacetic acid (TCA) was added and the tissue was homogenized using a mortar and pestle. The homogenate was filtered through Miracloth premoistened with TCA. The filtrate was vortexed with $0.1 \mathrm{~g}$ activated carbon and $0.04 \mathrm{~g}$ PVPP, then filtered through Miracloth again. The filtrate was centrifuged at $16,000 g_{n}$ for 15 min and the supernatant was used as crude plant extract. The 3 -mL reaction mixture contained $1.92 \mathrm{~mL} 0.375 \mathrm{~m}$ sodium phosphate buffer ( $\mathrm{pH}$ 6.5), $0.3 \mathrm{~mL} 3.3$ $\mathrm{mm}$ 3-dimethylaminobenzoic acid (DMAB), $0.3 \mathrm{~mL} 0.07 \mathrm{~mm}$ 3-methyl-2-benzothiazolinonehydrazone (MBTH), and $0.18 \mathrm{~mL}$ buffer containing $10 \mathrm{ng}$ type 1 horseradish peroxidase ( 0.25 units). All reagents were prepared in buffer, except MBTH, which was prepared in distilled water. The reaction was initiated by adding $0.3 \mathrm{~mL}$ crude plant extract containing about $1 \mathrm{mg}$ protein. Samples were incubated at $24^{\circ} \mathrm{C}$ for $24 \mathrm{~h}$ in the dark before measuring the absorbance at $590 \mathrm{~nm}$. The experiment was conducted on three dates with three subsamples from each crude plant extract assayed on each date. The experiment was a split-plot arrangement with species as the main-plot factor and temperature treatment as the subplot factor. Analysis of variance was performed using PROC MIXED (SAS Institute).

DPPH RADICAL SCAVENGING. DPPH is a relatively stable radical that absorbs strongly at $517 \mathrm{~nm}$ in the oxidized form (Masuda et al., 1999). Solutions scavenging the radical reduce absorbance as the purple color is diminished, allowing spectrophotometric determination of radical scavenging in plant extracts. The procedure of Masuda et al. (1999), with minor modifications, was employed to measure DPPH radical scavenging activity. Leaf tissue $(0.6 \mathrm{~g})$ was ground in $60 \mathrm{~mL}$ methanol in a mortar containing washed sand. The mortar, pestle, and methanol were prechilled to $4{ }^{\circ} \mathrm{C}$. The liquid was passed through Miracloth, then centrifuged at 16,000 $g_{\mathrm{n}}$ for $20 \mathrm{~min}$. The supernatant was pipetted into test tubes and diluted with methanol to produce solutions from 1.25 to $10 \mathrm{mg}$ fresh weight leaf tissue per mL solvent. Sixty microliters DPPH ( $5 \mathrm{mM}$ in methanol) was added to bring the total volume to 3 $\mathrm{mL}$, then tubes were vortexed. Duplicate samples were prepared without DPPH to subtract the background absorbance of the tissue solution. Absorbance at $517 \mathrm{~nm}$ was recorded using a spectrophotometer 30 min after adding DPPH. The tissue concentration reducing $\mathrm{A}_{517}$ by $50 \%, \mathrm{ED}_{50}$ (Abe et al., 1998), was calculated by linear interpolation. The assay was conducted using three replications derived from different plants. Three subsamples per treatment combination were assayed for each replication. Analysis of variance was performed using PROC GLM (SAS Institute) for the response variable $\mathrm{ED}_{50}$.

ThermostabiLity OF LEAF EXTRaCts. Leaf tissue (10.08 g) was homogenized in $175 \mathrm{~mL}$ MES (2-(N-morpholino)ethanesulfonic acid buffer (Sigma, St. Louis) (50 mM, pH 6.0) containing 1.08 g PVPP. Preliminary experiments with sweet pea and vinca leaf extracts prepared in distilled water yielded $\mathrm{pH}$ values of 6.0 for sweet pea and 6.1 for vinca extracts. Homogenates were filtered through Miracloth premoistened with buffer, then centrifuged at $16,000 g_{\mathrm{n}}$ for $20 \mathrm{~min}$ at $24^{\circ} \mathrm{C}$. Supernatants were placed in test tubes with $4 \mathrm{~mL}$ per tube and three tubes per treatment combination, then exposed to test temperatures for $15 \mathrm{~min}$. Sweet pea extracts were exposed to $24^{\circ} \mathrm{C}$ as a control, or 34 to $50{ }^{\circ} \mathrm{C}$ in $2{ }^{\circ} \mathrm{C}$ intervals. Test temperatures for vinca extracts were $24^{\circ} \mathrm{C}$ (control), or 38 to $58^{\circ} \mathrm{C}$ in $2{ }^{\circ} \mathrm{C}$ intervals. Three circulating baths at different temperatures were used to reduce the overall treatment duration. Test tubes removed from the high temperature treatments were placed in a water bath at $\approx 24{ }^{\circ} \mathrm{C}$ for $5 \mathrm{~h}$ before visual observations of precipitation and spectrophotometric determination of turbidity at $540 \mathrm{~nm}$ (Xu et al., 1998). Only the highest treatment temperatures for each species resulted in precipitation during or immediately after cooling. Turbid liquids either remained cloudy or formed macroscopic suspended aggregates that slowly settled to the bottom of the tubes over the course of the 5-h observation duration. It is likely that less turbid solutions that remained cloudy without forming precipitates in the bottom of the tubes would have formed precipitates eventually if the observation interval was extended beyond $5 \mathrm{~h}$. Insoluble material that settled to the bottom of the tube was avoided when sampling liquid over precipitates for turbidity measurements. Protein contents of plant extracts were determined colorimetrically (Bradford, 1976) using ovalbumen (Sigma) as the standard. The randomized, complete block experiment was conducted on four dates (blocks) with three subsamples from each crude plant extract assayed on each date. Analysis of variance was performed using PROC GLM (SAS Institute) for the response variables protein concentration and precipitation temperature.

\section{Results and Discussion}

Electrolyte leakage AND thermostability of CAT AND APOX. Vinca leaves were $5.5^{\circ} \mathrm{C}$ more thermotolerant than sweet pea leaves based on EL (Fig. 1A). Catalase activity was $6.0^{\circ} \mathrm{C}$ more thermostable in vinca compared with sweet pea leaves (Fig. 1B), and APOX activity was $2.6^{\circ} \mathrm{C}$ more thermostable in vinca than in sweet pea leaves (Fig. 1C). In addition to greater enzyme thermostability, control $\left(24^{\circ} \mathrm{C}\right.$ treatment $)$ activities of CAT and APOX were significantly greater in vinca leaves than in sweet pea. Control CAT activity was $65 \%$ greater and APOX activity was $161 \%$ higher in vinca controls than in sweet pea controls on a fresh weight basis. In vinca, $\mathrm{T}_{\text {mid }}$ values for APOX activity and $\mathrm{EL}$ were not significantly different $\left(52.9\right.$ and $53.9^{\circ} \mathrm{C}$, respectively), but were lower than $\mathrm{T}_{\text {mid }}$ for CAT $\left(56.0^{\circ} \mathrm{C}\right)$. In sweet pea, $\mathrm{T}_{\text {mid }}$ values for APOX and CAT activities were not significantly different from each other $\left(50.3\right.$ and $50.0^{\circ} \mathrm{C}$, respectively), but were higher than $\mathrm{T}_{\text {mid }}$ for $\mathrm{EL}\left(48.4^{\circ} \mathrm{C}\right)$.

Although few studies have explored thermal stability of AOS defenses in plants, factors related to heat stability of bacterial pathogens has been a focus in food safety studies. Dallmier and Martin(1988) reported that CAT activity was reduced significantly when Listeria monocytogenes cell extracts were heated above 50 ${ }^{\circ} \mathrm{C}$ for $10 \mathrm{~min}$. Temperatures causing a $50 \%$ reduction in activity ranged from 57.5 to $59.0^{\circ} \mathrm{C}$ for the four strains of bacteria. Dallmier and Martin (1988) also reported genetic differences in baseline activity of unstressed cells. However, a relationship between antioxidant enzyme activity and cellular thermotolerance was not observed, which supports the current study.

The mechanism of injury in heat-stressed tissue may involve an increase in the rate of production of AOS, impairment of antioxidant defenses, or both (Bowler et al., 1992). Direct involvement of $\mathrm{H}_{2} \mathrm{O}_{2}$ in heat stress injury would involve increased levels of endogenous $\mathrm{H}_{2} \mathrm{O}_{2}$, or increased sensitivity in heat-stressed plant tissue. If impaired enzymatic defenses contribute to injury, activities of antioxidant enzymes would decrease as the temperature increases, 
resulting in elevated AOS levels before or coincident with injury. In the present study, $\mathrm{T}_{\text {mid }}$ values for the $\mathrm{H}_{2} \mathrm{O}_{2}$-scavenging enzymes, CAT and APOX, were similar to or greater than $\mathrm{T}_{\text {mid }}$ values for EL in both plant species (Fig. 1). Temperature ranges in which

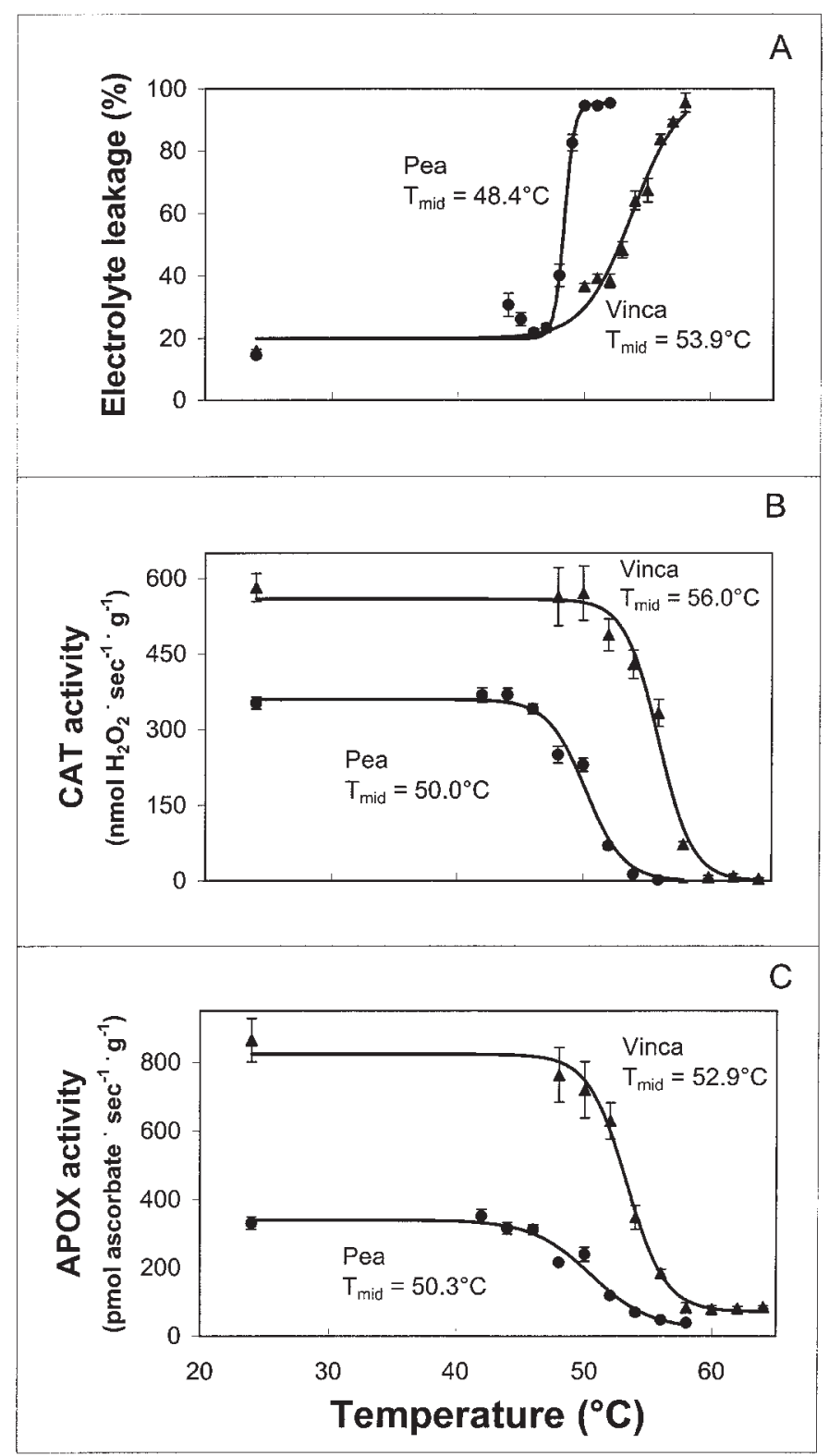

Fig. 1. Electrolyte leakage (A) and thermostability of catalase (CAT) (B) and ascorbate peroxidase (APOX) $(\mathbf{C})$ in 8-week-old vinca and sweet pea. Leaf tissues were exposed to the indicated temperature for $15 \mathrm{~min}$. Data represent means \pm SE of 15 measurements ( 5 replications with 3 subsamples). responses began differing from baseline levels were similar when comparing all three responses for a particular species. Ascorbate peroxidase activity in vinca leaves began decreasing between 48 and $52^{\circ} \mathrm{C}$, CAT activity started decreasing between 50 and 52 ${ }^{\circ} \mathrm{C}$, and EL started to increase by $50{ }^{\circ} \mathrm{C}$. Ascorbate peroxidase and CAT activities in sweet pea leaves began decreasing between 46 and $48^{\circ} \mathrm{C}$, and EL began increasing between 47 and $48^{\circ} \mathrm{C}$. Data were mostly consistent with coincident changes in membrane function, based on EL, and activities of $\mathrm{H}_{2} \mathrm{O}_{2}$-scavenging enzymes as temperature increased.

Loss of enzyme activities at elevated temperatures may be due to conformational changes, production of inhibitors, diminished rates of enzyme synthesis and/or elevated enzyme degradation. Acute heat stress injury probably involves changes in protein structure that impair enzymatic function. Differences in enzyme stability between vinca and sweet pea could involve more thermostable isozymes of CAT and APOX in vinca. Alternatively, enzyme thermostability may have been moderated by protective mechanisms, such as molecular chaperones (Nagao et al., 1990). Depending on the type and amount, the protective machinery could have provided greater thermoprotection to the enzymes in vinca than sweet pea.

HYDROGEN PEROXIDE LEVELS IN CONTROL, INJURED, AND KILLED TISSUES. Enzyme thermal stability provided only indirect information on the role of $\mathrm{H}_{2} \mathrm{O}_{2}$ in heat stress injury to vinca and sweet pea leaves. Therefore, a more direct approach was taken by measuring endogenous $\mathrm{H}_{2} \mathrm{O}_{2}$ levels in control, injured, and killed tissues. Temperature selection for each species was based on EL, with the injurious temperature corresponding to $\mathrm{T}_{\text {mid }}$ and the killing temperature representing the lowest temperature that led to the EL maximum (Fig. 1A). These categories were arbitrarily assigned because we did not track tissue responses to determine the effects of these temperatures on tissue viability. In vinca, EL was $22 \%$ at $24{ }^{\circ} \mathrm{C}$, increased to $64 \%$ at $54{ }^{\circ} \mathrm{C}$, and reached $94 \%$ at the killing temperature of $62{ }^{\circ} \mathrm{C}$ (Table 1). Similarly, in sweet pea leaves, EL was $23 \%$ at $24{ }^{\circ} \mathrm{C}$, increased to $59 \%$ at $48{ }^{\circ} \mathrm{C}$, and reached $93 \%$ at $54^{\circ} \mathrm{C}$. No significant differences in the level of $\mathrm{H}_{2} \mathrm{O}_{2}$ were observed across the exposure temperatures or between the two species (Table 1). If $\mathrm{H}_{2} \mathrm{O}_{2}$ played a role in heat stress injury, an increase in the level of $\mathrm{H}_{2} \mathrm{O}_{2}$ or an increase in tissue sensitivity to $\mathrm{H}_{2} \mathrm{O}_{2}$ at elevated temperatures would have been expected. Although we did not attempt to determine whether tissue sensitivity to $\mathrm{H}_{2} \mathrm{O}_{2}$ changed with increased temperature, endogenous $\mathrm{H}_{2} \mathrm{O}_{2}$ levels did not increase following heat stress.

MacRae and Ferguson (1985) reported similar results in pea (Pisum sativum L.), mung bean (Vigna radiata (L.) Wilczek.), and cucumber (Cucumis sativus L.) exposed to chilling stress. After chilling, they observed a significant decrease in CAT activity, however, $\mathrm{H}_{2} \mathrm{O}_{2}$ content was unchanged or decreased depending on the species. Despite decreased APOX and CAT activities, $\mathrm{H}_{2} \mathrm{O}_{2}$

Table 1. Electrolyte leakage (EL) and hydrogen peroxide $\left(\mathrm{H}_{2} \mathrm{O}_{2}\right)$ concentration in leaf tissue of 8-week-old vinca and sweet pea plants exposed to injurious or killing temperatures for $15 \mathrm{~min}$. Means $\pm \mathrm{SE}$ of nine measurements are reported.

\begin{tabular}{lcccr}
\hline $\begin{array}{l}\text { Leaf } \\
\text { tissue }\end{array}$ & Treatment & $\begin{array}{c}\text { Temp } \\
\left({ }^{\circ} \mathrm{C}\right)\end{array}$ & $\begin{array}{c}\text { EL } \\
(\%)\end{array}$ & $\begin{array}{c}\mathrm{H}_{2} \mathrm{O}_{2} \\
\left(\mu \mathrm{mol} \mathrm{g}^{-1} \mathrm{fresh} \mathrm{wt}\right)\end{array}$ \\
\hline Vinca & Control & 24 & $22.0 \pm 0.5 \mathrm{a}^{\mathrm{z}}$ & $2.7 \pm 0.2 \mathrm{a}$ \\
& Injured & 54 & $64.1 \pm 1.3 \mathrm{~b}$ & $3.1 \pm 0.4 \mathrm{a}$ \\
Kweet pea & Killed & 62 & $94.3 \pm 0.5 \mathrm{c}$ & $3.3 \pm 0.4 \mathrm{a}$ \\
& Control & 24 & $23.0 \pm 0.6 \mathrm{a}$ & $2.7 \pm 0.2 \mathrm{a}$ \\
& Injured & 48 & $58.7 \pm 2.4 \mathrm{~b}$ & $2.7 \pm 0.2 \mathrm{a}$ \\
\hline
\end{tabular}

${ }^{2}$ Means within a column followed by the same letter are not significantly different at $P \leq 0.05$ using LSD. 


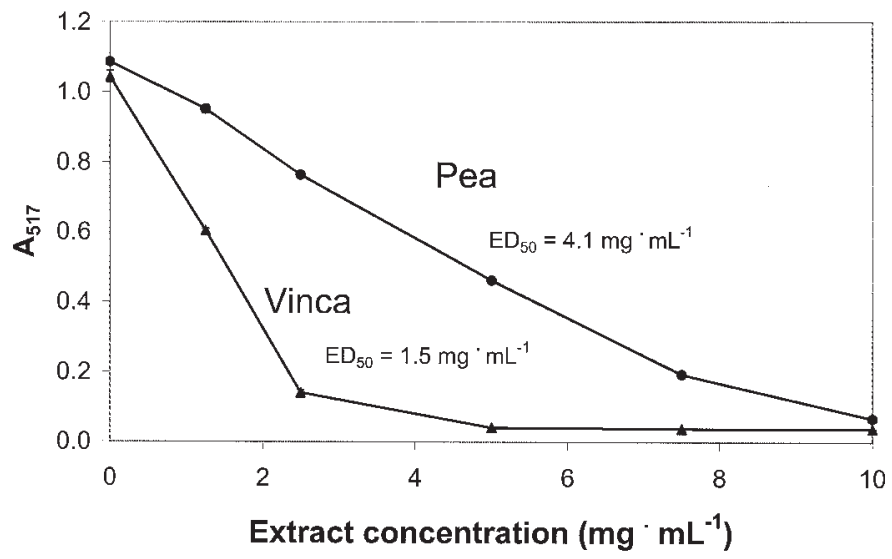

Fig. 2. Radical scavenging capacity of leaf extracts was estimated spectrophotometrically by DPPH reduction. Absorbance at $517 \mathrm{~nm}$ by methanolic extracts of vinca and sweet pea leaves containing $5 \mathrm{~mm} \mathrm{DPPH}$ was measured 30 min after addition of DPPH. Means \pm SE of nine measurements are reported.

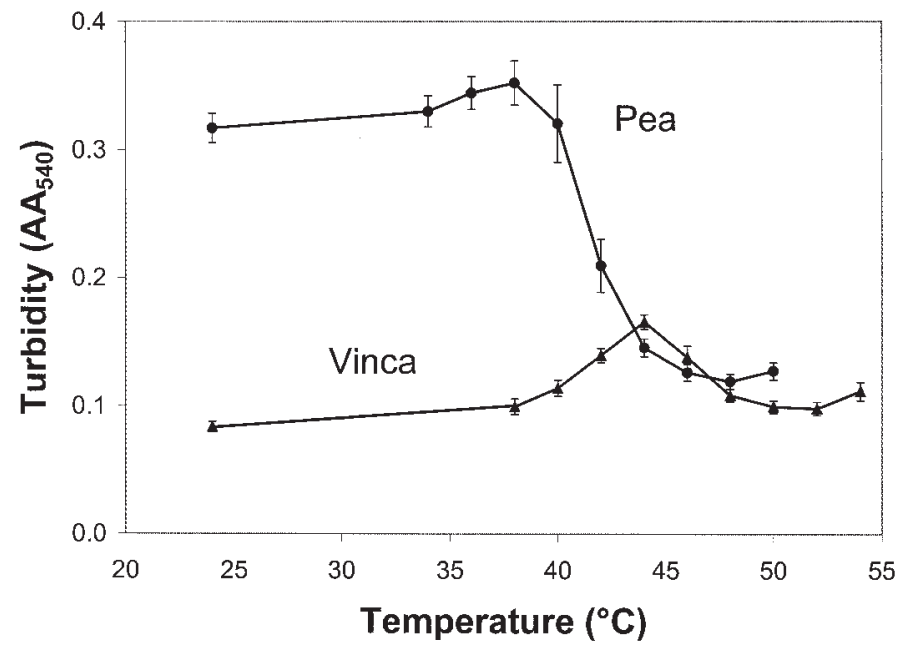

Fig. 3. Turbidity and precipitate formation in aqueous leaf extracts. Apparent absorbance at $540 \mathrm{~nm}$ by sweet pea and vinca leaf extracts after exposure to elevated temperatures for $15 \mathrm{~min}$. Precipitates formed at $\geq 40{ }^{\circ} \mathrm{C}$ in sweet pea extracts and at $\geq 46{ }^{\circ} \mathrm{C}$ in vinca extracts. Means \pm SE of nine measurements are reported.

decreased in rice (Oryza sativa L.) plants exposed to water stress (Boo and Jung, 1999). These studies suggest that impairment of enzyme defenses resulting in high levels of $\mathrm{H}_{2} \mathrm{O}_{2}$ may not be the mechanism of injury from chilling and water stress in these plants. However, another study found that $\mathrm{H}_{2} \mathrm{O}_{2}$ increased nearly $200 \%$ in rice shoot cultures chilled to $4^{\circ} \mathrm{C}$ (Fadzillah et al., 1996). Although APOX activity was unchanged, elevated $\mathrm{H}_{2} \mathrm{O}_{2}$ content was associated with decreased CAT activity. Increased $\mathrm{H}_{2} \mathrm{O}_{2}$ in chilled cucumber seedlings was also accompanied by a decrease in CAT activity (Omran, 1980). Apparently, the effects of chilling on $\mathrm{H}_{2} \mathrm{O}_{2}$ are a function of plant species and environmental conditions before and during chilling. A similar situation may hold for heat stress since $\mathrm{H}_{2} \mathrm{O}_{2}$ increased in mustard seedlings (Dat et al., 1998), but not in pepper (Anderson, 2002), or the vinca and sweet pea plants in the present study.

DPPH REDUCTION. Vinca leaves had significantly greater DPPH radical scavenging capacity than sweet pea leaves (Fig. 2). Vinca extracts at $2.5 \mathrm{mg} \cdot \mathrm{mL}^{-1}$ reduced absorbance by $87 \%$, but sweet pea extracts only lowered absorbance $30 \%$ at this concentration. $\mathrm{ED}_{50}$ values, the concentrations reducing absorbance by $50 \%$ (Abe et al., 1998), were $1.5 \mathrm{mg} \cdot \mathrm{mL}^{-1}$ for vinca and $4.1 \mathrm{mg} \cdot \mathrm{mL}^{-1}$ for sweet pea. Although the reactions involved, and their significance to stress injury are not known, the more thermotolerant plant had greater DPPH radical scavenging ability. Additional studies will be required to determine whether greater DPPH radical scavenging capacity translates to greater AOS poise in vivo.

Thermostability OF LEAF EXTRACTS. We observed precipitates forming in extracts heated to elevated temperatures during experiments examining the thermostability of CAT and APOX. Subsequent experiments were performed to determine if species differences in bulk protein stability existed in vinca and sweet pea leaves. Vinca leaf extracts were significantly more resistant to heat-induced changes in solubility than sweet pea extracts. Precipitates formed at $46.7 \pm 0.3^{\circ} \mathrm{C}$ in vinca extracts and at $40.5 \pm$ $0.3^{\circ} \mathrm{C}$ in sweet pea (Fig. 3). As exposure temperatures increased from ambient $\left(24{ }^{\circ} \mathrm{C}\right)$, turbidity increased to a maximum, then decreased as precipitates formed. Our observations of increasing turbidity followed by precipitation as temperatures increased were consistent with previous studies using egg white solids. $\mathrm{Xu}$ et al. (1998) described both soluble (turbid) and insoluble (coagulated) materials after heating. Vinca extracts were more thermostable than sweet pea extracts even though they contained significantly more protein (4.1 vs $3.0 \mathrm{mg} \cdot \mathrm{mL}^{-1}$ extract). Control pea extracts were significantly more turbid than vinca controls in spite of a lower protein content, indicating that additional factors contributed to turbidity.

Turbidity development and precipitation in crude leaf extracts appears to be useful in examining bulk protein thermostability, similar to studies with individual proteins (Park et al., 2002), egg white solids (Xu et al., 1998), and protein-chaperone mixtures (Lee and Vierling, 1998). However, additional factors are involved in protoplasmic coagulation since $\approx 70 \%$ of the proteins remained in solution following coagulation (data not presented).

In conclusion, differences in intrinsic thermotolerance between vinca and sweet pea leaves were correlated with DPPH radical scavenging activity and protein thermal stability. Although CAT and APOX activity were greater and more thermostable in vinca than sweet pea, differences in $\mathrm{H}_{2} \mathrm{O}_{2}$ were not observed following heat stress. Therefore, it is not likely that $\mathrm{H}_{2} \mathrm{O}_{2}$ plays a direct role in acute heat stress injury in these plants. However, the role of $\mathrm{H}_{2} \mathrm{O}_{2}$ and $\mathrm{H}_{2} \mathrm{O}_{2}$ defenses in acclimation responses has been established (Foyer et al., 1997; Kang and Saltveit, 2002). It would be instructive to further our understanding of plant thermotolerance by determining the nature of the involvement of reducing power and protein stability.

\section{Literature Cited}

Abe, N., T. Murata, and A. Hirota. 1998. Novel DPPH radical scavengers, bisorbicillinol and demethyltrichodimerol, from a fungus. Biosci. Biotechnol. Biochem. 62:661-662.

Aebi, H.E. 1983. Catalase, p. 273-286. In: H.V.Bergmeyer(ed.). Methods of enzymatic analysis. Verlag, Weinheim.

Alscher, R.G., J.L. Donahue, and C.L. Cramer. 1997. Reactive oxygen species and antioxidants: Relationships in green cells. Physiol. Plant. 100:224-233.

Anderson, J.A. 2002. Catalase activity, hydrogen peroxide content and thermotolerance of pepper leaves. Scientia Hort. 95:277-284.

Basaga, H.S. 1989. Biochemical aspects of free radicals. Biochem. Cell Biol. 68:989-998.

Boo, Y.C. and J. Jung. 1999. Water deficit-induced oxidative stress and antioxidant defenses in rice plants. J. Plant Physiol. 155:255-261.

Bowler, C.M., M. Van Montagu, and D. Inze. 1992. Superoxide dismutase and stress tolerance. Annu. Rev. Plant Physiol. Plant Mol. Biol. 43:83-116. 
Bradford, M.M. 1976. A rapid and sensitive method for the quantitation of microgram quantities of protein utilizing the principle of protein-dye binding. Anal. Biochem. 72:248-254.

Buchner, J., H. Grallert, and U. Jakob. 1998. Analysis of chaperone function using citrate synthase as nonnative substrate protein. Meth. Enzymol. 290:323-338.

Dallmier,A.W. and S.E. Martin. 1988. Catalase and superoxide dismutase activities after heat injury of Listeria monocytogenes. Appl. Environ. Microbiol. 54:581-582.

Dat, J.F., H. Lopez-Delgado, C.H. Foyer, and I.M. Scott. 1998. Parallel changes in $\mathrm{H}_{2} \mathrm{O}_{2}$ and catalase during thermotolerance induced by salicylic acid or heat acclimation in mustard seedlings. Plant Physiol. 116:1351-1357.

del Rio, L.A., G.M. Pastori, J.M. Palma, L.M. Sandalio, F. Sevilla, F.L. Corpas, A. Jiménez , E. López-Huertas, and J.A. Hernández. 1998. The activated oxygen role of peroxisomes in senescence. Plant Physiol. 116:1195-1200.

Desikan, R., J.T. Hancock, M.J. Coffey, and S.J. Neill. 1996. Generation of active oxygen in elicited cells of Arabidopsis thaliana is mediated by a NADPH oxidase-like enzyme. FEBS Lett. 382:213-217.

Dhindsa, R.S., P. Plumb-Dhindsa, and T.A. Thorpe. 1981. Leaf senescence: correlated with increased levels of membrane permeability and lipid peroxidation, and decreased levels of superoxide dismutase and catalase. J. Expt. Bot. 32:93-101.

Elstner, E.F. 1982. Oxygen activation and oxygen toxicity. Annu. Rev. Plant Physiol. 33:73-96.

Fadzillah, N.M., V. Gill, R.P. Finch, and R.H. Burdon. 1996. Chilling, oxidative stress and antioxidant responses in shoot cultures of rice. Planta 199:552-556.

Foyer, C.H., P. Descourvieres, and K.J. Kumar. 1994. Protection against oxygen radicals: an important defense mechanism studied in transgenic plants. Plant Cell Environ. 17:507-523.

Foyer, C.H., H. Lopez-Delgado, J.H. Dat, and I.M. Scott. 1997. Hydrogen peroxide and glutathione-associated mechanisms of acclimatory stress tolerance and signaling. Physiol. Plant. 100:241-254.

Gross, G.G. 1980. The biochemistry of lignification. Adv. Bot. Res. 8: 25-63.

Ingram, D.L. 1985. Modeling high temperature and exposure time interactions on Pittosporum tobira root cell membrane thermostability. J. Amer. Soc. Hort. Sci. 110:470-473.

Jakob, U., H. Lilie, I. Meyer, and J. Buchner. 1995. Transient interaction of Hsp90 with early unfolding intermediates of citrate synthase. J. Biol. Chem. 270:7288-7294.

Kang, H. and M.E. Saltveit. 2002. Antioxidant enzymes and DPPH-radical scavenging activity in chilled and heat-shocked rice (Oryza sativa L.) seedlings radicles. J. Agr. Food Chem. 50:513-518.

Larson, R.A. 1988. The antioxidants of higher plants. Phytochemistry 27:969-978.

Lee, G.J. and E. Vierling. 1998. Expression, purification, and molecular chaperone activity of plant recombinant small heat shock proteins. Meth. Enzymol. 290:350-365.

Levitt, J. 1980. Responses of plants to environmental stresses. vol. 1. Chilling, freezing and high temperature stresses. Academic Press, New York.

Liu, X. and B. Huang. 2000. Heat stress injury in relation to membrane lipid peroxidation in creeping bentgrass. Crop Sci. 40:503-510.

MacRae, E.A. and I.B. Ferguson. 1985. Changes in catalase activity and hydrogen peroxide concentration in plants in response to low temperature. Physiol. Plant. 65:51-56.

Masuda, T., S. Yonemori, Y. Oyama, Y. Takeda, T. Tanaka, T. Andoh, A. Shinohara, and M. Nakata. 1999. Evaluation of the antioxidant activity of environmental plants: Activity of the leaf extracts from seashore plants. J. Agr. Food Chem. 47:1749-1754.

Miyake, C., F. Michihata, and K. Asada. 1991. Scavenging of hydrogen peroxide in prokaryotic and eukaryotic algae: Acquisition of ascorbate peroxidase during the evolution of cyanobacteria. Plant Cell Physiol. 32:33-43.

Nagao, R.T., J.A. Kimpel, and J.L. Key. 1990. Molecular and cellular biology of the heat-shock response. Adv. Genet. 28:235-274.

Nanaiah, G.K. and J.A. Anderson. 1992. Electrolyte leakage and evolution of ethylene and ethane from pepper leaf disks following temperature stress and fatty acid infiltration. J. Amer. Soc. Hort. Sci. 117:846-851.

Ngo, T.T. and H.M. Lenhoff. 1980. A sensitive and versatile chromogenic assay for peroxidase and peroxidase-coupled reactions. Anal. Biochem. 105:389-397.

Noctor, G. and C.H. Foyer. 1998. Ascorbate and glutathione: Keeping active oxygen under control. Annu. Rev. Plant Physiol. Plant Mol. Biol. 49:249-279.

Omran, R.G. 1980. Peroxide levels and activities of catalase, peroxidase and indoleacetic oxidase during and after chilling cucumber seedlings. Plant Physiol. 65:407-408.

Park, S.M., H.Y. Jung, K.C. Chung, H. Rhim, J.H. Park, and J. Kim. 2002. Stress-induced aggregation profiles of GST- $\alpha$-synuclein fusion proteins: Role of the $\mathrm{C}$-terminal acidic tail of $\alpha$-synuclein in protein thermosolubility and stability. Biochemistry 41:4137-4146.

Prasad, K.V.S.K., P.P. Saradhi, and P. Sharmila. 1999. Concerted action of antioxidant enzymes and curtailed growth under zinc toxicity in Brassica juncea. Environ. Expt. Bot. 42:1-10.

Prasad, T.K., M.D. Anderson, B.A. Martin, and C.R. Stewart. 1994. Evidence of chilling-induced oxidative stress in maize seedlings and a regulatory role for hydrogen peroxide. Plant Cell 6:65-74.

Sairam, R.K., G.C. Srivastava, and D.C. Saxena. 2000. Increased antioxidant activity under elevated temperatures: a mechanism of heat stress tolerance in wheat genotypes. Biol. Plant. 43:245-251.

Sala, J.M. and M.T. Lafuente. 1999. Catalase in heat-induced chilling tolerance of cold-stored hybrid Fortune mandarin fruits. J. Agr. Food Chem. 47:2410-2414.

Salvucci, M.E., K.W. Osteryoung, S.J. Crafts-Brandner, and E. Vierling. 2001. Exceptional sensitivity of rubisco activase to thermal denaturation in vitro and in vivo. Plant Physiol. 127:1053-1064.

Shewfelt, R.L. and A.C. Purvis. 1995. Toward a comprehensive model for lipid peroxidation in plant tissue disorders. HortScience 30: 213-218.

Veljovic-Jovanovic, S. 1998. Active oxygen species and photosynthesis: Mehler and ascorbate peroxidase reactions. Yugoslav. Physiol. Pharmacol. Acta 34:503-522.

Wise, R.R. and A.W. Naylor. 1987. Chilling-enhanced peroxidation. The peroxidative destruction of lipids during chilling injury to photosynthesis and ultrastructure. Plant Physiol. 83:272-277.

Xu, J.Q., M. Shimoyamada, and K. Watanabe. 1998. Heat aggregation of dry-heated egg white and its inhibiting effect on heat coagulation of fresh egg white. J. Agr. Food Chem. 46:3027-3032. 